\title{
Application of Electrochemical Processes to Classical lodocyclisation: Utility for Selectivity and Mechanistic Insight.
}

\author{
Diyuan Li, ${ }^{[\mathrm{a}]}$ Peter W. Seavill, ${ }^{[\mathrm{a}]}$ and Jonathan D. Wilden ${ }^{[\mathrm{a}] *}$
}

\begin{abstract}
The hazards and difficulties of handling elemental halogens such as $I_{2}$ can be circumvented via electrochemical generation of these species in situ and 'on-demand'. Advantages of this approach include the halogen being introduced into the reaction mixture at a steady rate ensuring low concentrations to prevent halogenation of reactive aromatic rings. We also demonstrate that the Lewis acid required to promote this reaction, a $\mathrm{Zn}$ (II) salt, can also be generated in situ from a zinc-coated graphite electrode in a clean and energy efficient manner. Mechanistic studies indicate an unusual pathway which provides selectivity for the iodocyclisation without the oftenproblematic electrophilic aromatic iodination of the aryl ring.
\end{abstract}

\section{Introduction}

lodocyclisation of alkenes with oxygen nucleophiles is a powerful method of generating furan and benzofuran frameworks that maintain the iodine functionality and thereby allow further manipulation..$^{1-5}$ The benzofuran motif is an important framework in a variety of natural products and drug substances and as such, rapid and efficient processes for the construction of substituted variants via the construction of the bicyclic nucleus are synthetically valuable. ${ }^{6-13}$ With our own research interests in practical electrochemical processes we here report an efficient route for the construction of the dihydrobenzofuran framework through an iodoetherification reaction of 2-allylphenols where the molecular iodine and a Lewis acid are electrochemically generated from benign starting materials. Examples of iodocyclisation of phenols onto alkenes are conspicuously sparse in the literature with only a few examples being noted. ${ }^{14-15}$ Unlike other iodocyclisation reactions in organic media, those employing alkenes and phenolic nucleophiles require a Lewis acid additive (which can be toxic such as a $\mathrm{Hg}$ (II) salt) suggesting an alternative mechanistic pathway compared to classical reactions which are usually rapid and do not require a Lewis acid additive. We were

[a] D. Li, P. W. Seavill and Dr J. D. Wilden

Department of Chemistry,

University College London

20 Gordon Street,

London,

WC1H OAJ, UK

Email: j.wilden@ucl.ac.uk

Supporting information for this article, including characterisation data and details of the electrochemical cell used can be found at https://doi.org./ also keen to see if we could further explore this mechanistic pathway as well as developing a new reaction process.

Having demonstrated previously that organic reactions could be promoted under electrochemical conditions via release of a metal catalyst from a coated electrode,$^{16}$ and with our interest in the development of processes of industrial relevance, we wished to examine if a similar approach could be applied here. We envisaged that a zinc-coated carbon electrode could release a reactive $\mathrm{Zn}$ (II) Lewis acid catalyst into solution through the application of an oxidative potential. When the zinc coating is exhausted, it was then anticipated that molecular iodine would be generated allowing the iodocyclisation to occur. The proposed process is outlined in Scheme 1.

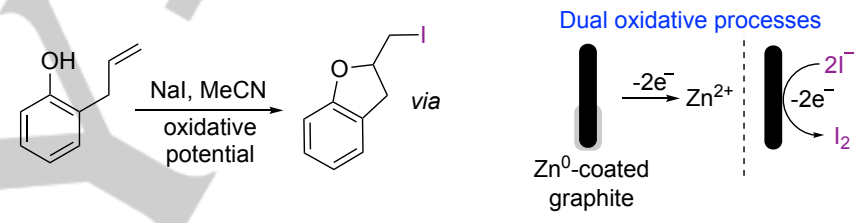

Scheme 1. Proposed electrochemical cyclisation using dual oxidative processes.

Such an approach would circumvent the necessity to handle reactive intermediates $\left(\mathrm{I}_{2}\right.$ and $\left.\mathrm{ZnI}_{2}\right)$ which might be particularly valuable for industrial process development. Our other work has focused on recovering metal additives via electrochemistry and could also be applied here. ${ }^{16}$

\section{Results and Discussion}

We began by coating a graphite rod with zinc metal in the same fashion as we have described previously. ${ }^{16}$ This is easily achieved by applying a reducing potential to a graphite rod in a solution of $2 \mathrm{M} \mathrm{Na}_{2} \mathrm{CO}_{3}$ with a zinc rod as the counter electrode. The nature of the electrochemical technique allows us to accurately measure the amount of zinc plated onto the electrode via the charge passed. Classically, 0.5 eq of a $\mathrm{Zn}$ (II) or Sn(IV) Lewis acid is employed to effect this cyclisation, ${ }^{14-15}$ with either 0.5 eq or 1.0 eq of iodine, although neither stoichiometry of the Lewis acid or the halogen has been fully explained.

In order to develop our process, we first needed to establish the electrochemical conditions required for: (i) oxidative release of $\mathrm{Zn}^{2+}$ from the zinc-coated electrode and (ii) oxidation of $\mathrm{Nal}$ to molecular iodine. Since the standard reduction potential of $\mathrm{Zn}^{2+}$ is significantly lower than for $\mathrm{I}_{2}(-0.76 \mathrm{~V}$ vs $+0.54 \mathrm{~V}$ vs SHE) we realized that any potential required to oxidise $\mathrm{Nal}$ would first oxidise the zinc coating and would allow us to generate both species in a single reaction vessel using a constant potential. 
Accordingly, we examined a solution of $\mathrm{Nal}$ using cyclic voltammetry $(\mathrm{CV})$ to determine the potential that would be required to generate the halogen.

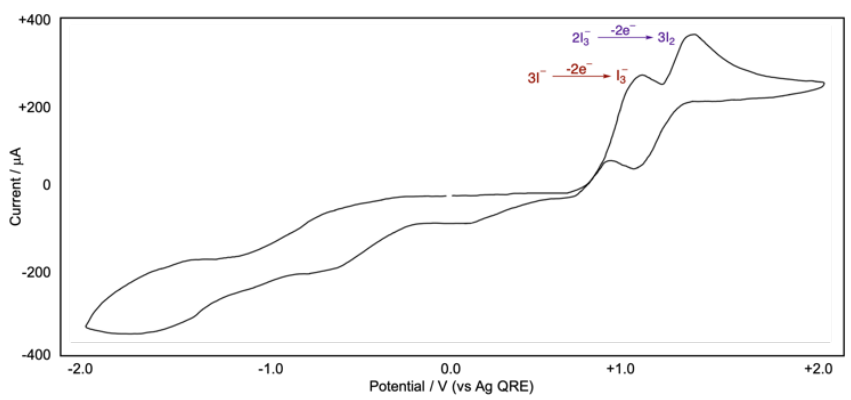

Figure 1. Representative $\mathrm{CV}$ of $\mathrm{Nal}(0.1 \mathrm{M})$ using a glassy carbon working electrode and a platinum counter electrode in $0.1 \mathrm{M} \mathrm{LiClO}_{4}$ in $\mathrm{MeCN}$.

Figure 1 shows the $\mathrm{CV}$ of $\mathrm{Nal}$ and is consistent with halide salts examined in the literature. ${ }^{17-18}$ The first oxidation occurring at ca. +1.0 V (vs Ag Quasi-Reference Electrode QRE) indicates the oxidation of iodide to triiodide $\left(\mathrm{I}_{3}{ }^{-}\right)$followed by subsequent oxidation of $\mathrm{I}_{3}{ }^{-}$to $\mathrm{I}_{2}$ at ca. $+1.4 \mathrm{~V}$. Since triiodide is a known oxidant and is also known to be in equilibrium with molecular iodine,$^{17-18}$ we decided to attempt an electrochemically-controlled iodoetherification reaction at $+1.2 \mathrm{~V}$. Pleasingly, application of $+1.2 \mathrm{~V}$ to a zinc-coated graphite electrode $(40 \mathrm{~mol} \% \mathrm{Zn}(0))$ in a divided ' $\mathrm{H}$-cell' (experimental details in supporting information) in the presence of $\mathrm{Nal}(0.1 \mathrm{M})$ and commercially-available 2allylphenol yielded the cyclized product in excellent yield (Scheme 2).
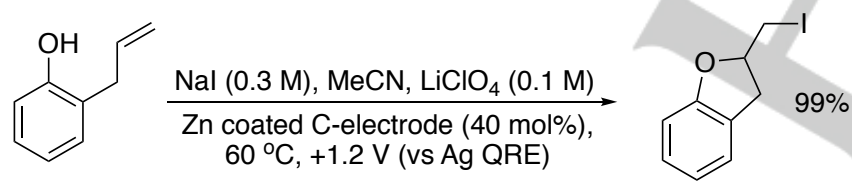

Scheme 2. Successful electrochemical cyclisation conditions.

Encouraged by this result we wanted to test our process with a more diverse array of substrates. In order to do this, we needed a reliable method of preparing an array of substituted 2-allylphenols. As a well-known and explored reaction we firstly turned to the classical Claisen rearrangement. Although this reaction is known to proceed in good yields under various conditions at high temperatures $\left(>190^{\circ} \mathrm{C}\right)$, in our hands we found these procedures capricious and often inconvenient (and not amenable to scale up synthesis). We found however, that the reaction could be promoted smoothly and in good yields at the 'standard' temperature of $200{ }^{\circ} \mathrm{C}$ by the addition of a small quantity (1-2 drops) of ethylene glycol. Crucially, no solvent is required meaning that the reaction can be carried out on a multigram scale with relative ease as shown in Scheme 3.

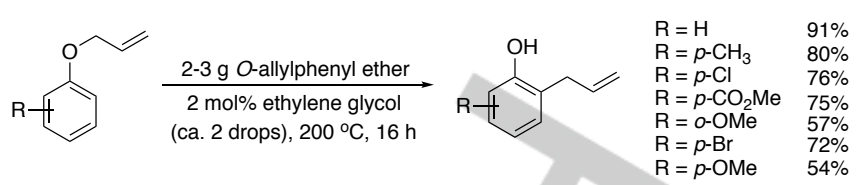

Scheme 3. Preparation of substrates for electro-cyclisation by Claisen rearrangement.

With an array of 2-allylphenols in hand, we then embarked on converting these to iodinated dihydrobenzofurans using our process outlined in Scheme 2. Pleasingly, in all cases, cyclisation occurred smoothly and in good yield (Table 1). Although these reactions take longer than the most comparable in the literature, ${ }^{15}$ yields are generally higher, probably due to the slow generation of iodine in situ leading to a lower and more even concentration of the reagent compared to the addition of the bulk reagent.

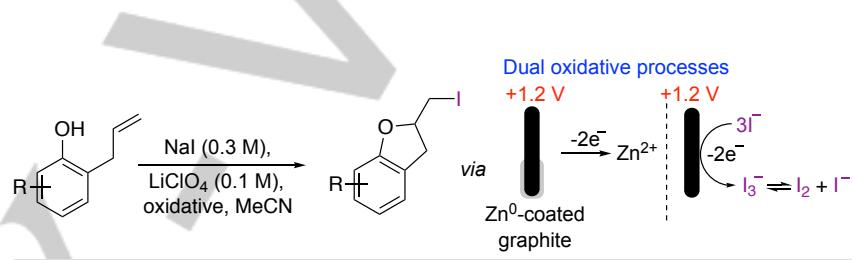

Table 1. Electrochemically-mediated Cyclisation of 2-allylphenols

\begin{tabular}{|c|c|c|c|c|}
\hline Entry & Electrode & Conditions & $\mathrm{R}$ & $\%$ yield ${ }^{[a]}$ \\
\hline 1 & Graphite & No potential & $\mathrm{H}$ & 0 \\
\hline 2 & $\begin{array}{c}\mathrm{Zn} \mathrm{(40} \mathrm{mol \% -} \\
\text { coated Graphite }\end{array}$ & No potential & $\mathrm{H}$ & 0 \\
\hline 3 & Zinc metal & $+1.2 \mathrm{~V}$ & $\mathrm{H}$ & 0 \\
\hline 4 & No electrode & $\begin{array}{l}\text { No potential, } \mathrm{I}_{2} \text {, } \\
\mathrm{ZnCl}_{2}(1.0 \text { eq. }\end{array}$ & $\mathrm{H}$ & $>99$ \\
\hline 5 & Graphite & $+1.2 \mathrm{~V}$ & $\mathrm{H}$ & 0 \\
\hline 6 & $\begin{array}{l}\text { Zn (10 mol\%)- } \\
\text { coated graphite }\end{array}$ & $+1.2 \mathrm{~V}$ & $\mathrm{H}$ & Trace \\
\hline 7 & $\begin{array}{l}\text { Zn (20 mol\%)- } \\
\text { coated graphite }\end{array}$ & $+1.2 \mathrm{~V}$ & $\mathrm{H}$ & 60 \\
\hline 8 & $\begin{array}{l}\text { Zn (40 mol\%)- } \\
\text { coated graphite }\end{array}$ & $+1.2 \mathrm{~V}$ & $\mathrm{H}$ & 99 \\
\hline $9^{[b]}$ & $"$ & $+1.2 \mathrm{~V}$ & $\mathrm{H}$ & 0 \\
\hline 10 & $"$ & $+1.2 \mathrm{~V}$ & $p-\mathrm{CH}_{3}$ & 93 \\
\hline 11 & $"$ & $+1.2 \mathrm{~V}$ & $p-\mathrm{Cl}$ & 81 \\
\hline 12 & $"$ & $+1.2 \mathrm{~V}$ & $p-\mathrm{CO}_{2} \mathrm{Me}$ & 67 \\
\hline 13 & $"$ & $+1.2 \mathrm{~V}$ & o-OMe & 64 \\
\hline 14 & $"$ & $+1.2 \mathrm{~V}$ & $p-B r$ & 83 \\
\hline 15 & $"$ & $+1.2 \mathrm{~V}$ & p-OMe & 79 \\
\hline
\end{tabular}

[a] Isolated yield. [b] Reaction conducted at room temperature. 
Employing the electrochemical technique also allowed us to measure the charge passed during the course of the experiment, as in Figure 2. A clear change in gradient can be seen at $10 \mathrm{ks}$ which represents the exhaustion of zinc from the coated electrode and where the oxidation of $\mathrm{I}^{-}$begins

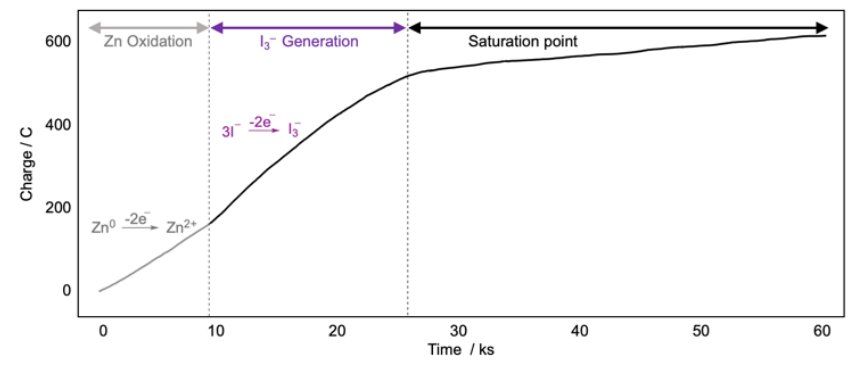

Figure 2: Charge-time profile indicating the generation of $\mathrm{Zn}^{2+}$ followed by the oxidation of $\mathrm{I}^{-}$.

Having established this new approach for the iodocyclisation, we also wished to further examine the reaction mechanism. In particular, we were intrigued as to why the generation of a putative electrophilic iodinating agent did not result in iodination of the electron-rich aromatic ring in any of the examples we examined. Accordingly, we first chose to confirm that the alkene was firstly not oxidized to the radical cation at the electrode and also that it was unreactive to iodine / $\mathrm{Nal}$ in the absence of the other reagents. Cyclic voltammetry of allylbenzene firstly confirmed that the alkene was not electrochemically active, with no redox events being observed between the solvent's usual stability limits. The lack of reactivity towards $\mathrm{I}_{2} / \mathrm{Nal}$ was tested in Table 1 (Entry 5) where iodine was generated in the absence of a Lewis acid, and no cyclisation occurred. Similarly, when we exposed allylbenzene to $I_{2} / \mathrm{Nal}$ and $\mathrm{ZnCl}_{2}$ (Scheme 4), no reaction was observed and the starting allylbenzene was recovered quantitatively. In order to probe whether the phenolic moiety was more intricately involved in the mechanistic pathway we then attempted this reaction with one equivalent of 2,4,6trimethylphenol. Again, as expected, no reaction was observed. Finally, we undertook the same process with all of the components added; allylbenzene, $I_{2} / \mathrm{Nal}, \mathrm{ZnCl}_{2}$, and 2,4,6trimethylphenol. In this case we were surprised to observe that small, but significant, quantities (ca. 10\%) of difunctionalised product 1 were produced. Tellingly, the iodoether was generated despite an excess of $\mathrm{Nal}$ being present. The results are outlined in Schemes 4a-c:

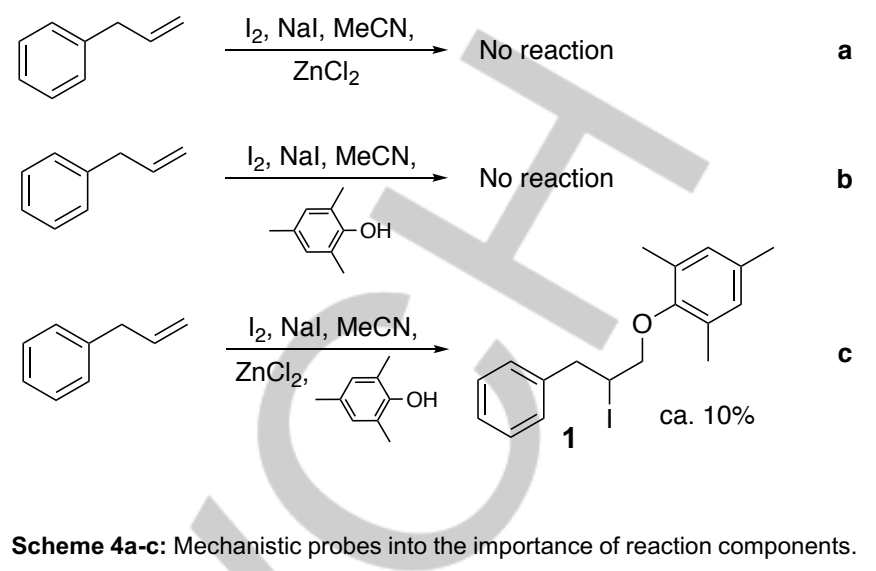

As shown in Figure 2, the predominant active iodine species in the reaction mixture will be triiodide given that at any one point, only low concentrations of iodine will be present compared to that of iodide. At this point, we could not rule out the possibility that an active iodine species was reversibly generating a cycloiodonium ion (in low concentrations) which was then interacting with the zinc salt of the phenol to yield the product observed in Scheme 2. If this were the case, then it would be expected that the addition of a base would accelerate the reaction by facilitating the formation of the zinc-phenol complex. When we attempted the reaction outlined in Scheme 2 with one equivalent of added $\mathrm{K}_{2} \mathrm{CO}_{3}$, no acceleration in rate was observed and rather than cleanly isolating the cycloiodinated product, only a small amount of the cyclized material was produced. The majority of the isolated material comprised products of arene iodination. Similarly, when the reaction was performed in the presence of $\mathrm{K}_{2} \mathrm{CO}_{3}$ and the absence of a zinc Lewis acid, only iodinated arenes were observed. This suggests that although a cycloiodinium ion may form under these conditions, an alternative pathway is required to give the clean cyclized products. It also suggests that a process that 'protects' the activated aromatic ring from iodination is also in operation.

These observations along with the results outlined in Scheme $4 a-c$ are significant since they rule out the possible interaction between the Lewis acid and molecular iodine in generating the reactive iodinating species. Instead we suggest that a transient iodosylaryl species, such as $\mathbf{2}$, is responsible. Accordingly, this would suggest a reaction pathway for cyclisation of 2-allylphenols to be that shown in Scheme 5: 


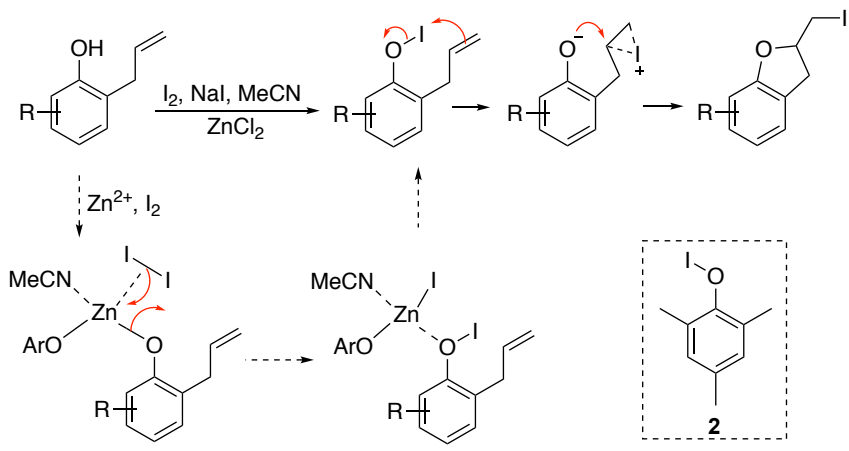

Scheme 5: Proposed mechanistic pathway.

This is unsurprising given that $\mathrm{Zn}(\mathrm{II})$ is a hard Lewis acid and molecular iodine is a soft electrophile and therefore unlikely to efficiently interact. Furthermore, a consultation of the literature reveals that zinc-phenoxy complexes, (particularly zinc bis(aryloxy) compounds) have been prepared by reaction of a zinc(II) salt with the deprotonated phenol and are stable in aprotic solvents. ${ }^{19}$ As such, we suggest that the most likely mechanistic pathway consistent with our observations is the initial formation of a bis(aryloxy)zinc complex, analogous to those described previously, followed by coordination of $I_{2}$. Metathesis of the $\mathrm{I}-\mathrm{I}$ and $\mathrm{Zn}-\mathrm{O}$ bonds then leads to the reactive iodophenoxy intermediate (possibly still coordinated to the Lewis acid providing further activation).

Finally, we were intrigued as to why the generation of powerful iodinating species rarely lead to the observation of any iodinated aromatic products despite the rings in some examples being highly activated. This observation seems to contradict many known iodination protocols that employ either iodine or active iodine species under seemingly similar conditions $\mathrm{s}^{20-21}$ and our own observations that ring iodination was observed with added base. We therefore wondered if iodination was indeed occurring as would be expected, but in the absence of base the reverse reaction was occurring due to the in situ formation of $\mathrm{HI}$ (Scheme $6)$.

$\mathrm{I}_{2}$<smiles>C=CCc1ccccc1O</smiles>
$\mathrm{I}_{2}+$

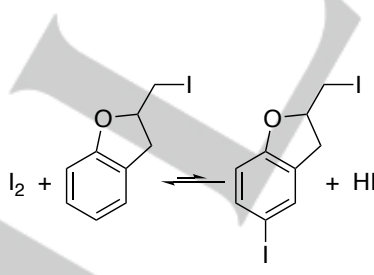

Scheme 6: Possible aromatic ring iodination in equilibrium with $\mathrm{HI}$.

In order to test this hypothesis, we chose to examine the model systems of 4-iodophenol and 4-iodoanisole under our reaction conditions to see if the iodine atom in those species was labile. By performing the experiments under electrochemical conditions (generating $\mathrm{Zn}^{2+}$ from a zinc-coated graphite electrode and $\mathrm{I}_{2}$ via oxidation of $\mathrm{Nal}$ as outlined in Scheme 1) we could be sure that the Lewis acid was dry (zinc halides are notoriously hygroscopic) so that we could conclude that water was unlikely to be involved in the process. Similarly, the electrochemical generation of $\mathrm{I}_{2}$ would allow us to determine that this was the initial reactive iodine species formed and not more powerful iodinating agents such as $\mathrm{ICl}$ generated from the zinc salt counterion. Accordingly, we performed the reactions outlined in Schemes 7 using $\mathrm{MeSO}_{3} \mathrm{H}$ (2 eq.) as a strong acid to mimic the presence of $\mathrm{HI}$ :

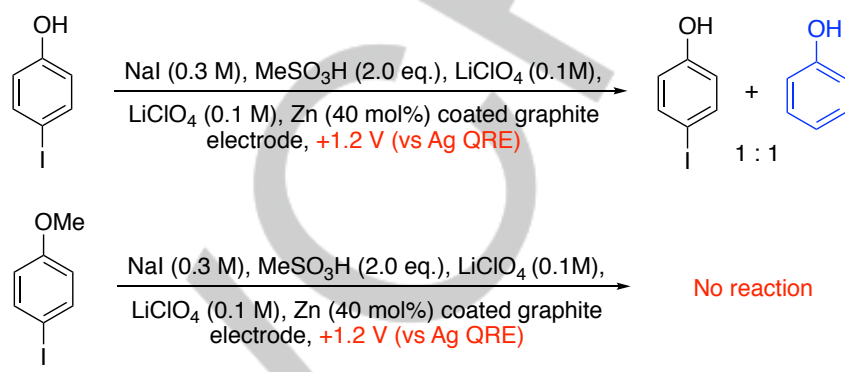

Scheme 7: Test of aromatic ring iodination in the presence of an $\mathrm{HI}$ mimic, $\mathrm{MeSO}_{3} \mathrm{H}$.

The results outlined in Scheme 7 show that in the phenolic system, the iodine is labile, however in the alkylated variant the iodine atom is resistant to reductive exchange. This suggests that an equilibrium between iodinated and unsubstituted 2-allylphenol is established prior to cyclisation. Of these two compounds, the iodinated species is more resistant to the formation of the required reactive intermediate due to the electron-withdrawing nature of the iodine atom attached to the aromatic ring. ${ }^{22}$ Consequently, cyclisation occurs most rapidly via the unsubstituted system leading to the dihydrobenzofuran (Scheme 8).

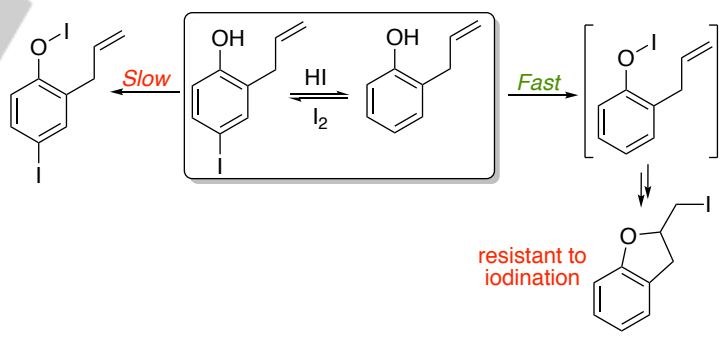

Scheme 8: Proposed rationale for the absence of iodinated aromatic products.

\section{Conclusions}

In conclusion, we have established an electrochemical method of generating both $\mathrm{I}_{2}$ and $\mathrm{Zn}$ (II) Lewis acid in situ from stable and non-toxic starting materials which can then be employed to effect efficient iodocyclisations. The protocol is competitive with the traditional method of employing bulk reagents, however, also engages the 'green' and sustainable credentials of electrochemical synthesis. Furthermore, we have used our technique to assist in our mechanistic investigations and have concluded that the reaction pathway involves a transient iodoxyphenolic intermediate which is the active oxidant. We have 
also shown that excessive iodination of the activated phenolic rings is avoided via a reversible deiodination process and that the cyclized dihydrobenzofuran is less activated towards iodination which leads to extremely good yields of the desired products.

\section{Experimental Section}

General procedure for the preparation of $\mathbf{O}$-allylphenols. To a flame-dried flask with a mixture of phenol $(1.0 \mathrm{eq})$ and potassium carbonate $(1.5 \mathrm{eq})$ in anhydrous $\mathrm{MeCN}(20 \mathrm{~mL})$, allyl bromide $(1.5 \mathrm{eq})$ was added dropwise. The reaction mixture was then allowed to heat to $60{ }^{\circ} \mathrm{C}$ and stirred for $16 \mathrm{~h}$ before being cooled to room temperature. The $\mathrm{MeCN}$ was then removed under vacuum and the crude product was washed with water and brine and extracted with DCM $(3 \times 20 \mathrm{~mL})$. The organic layer was dried over magnesium sulfate and concentrated under vacuum to give the O-allylphenol product.

4-Methylphenyl allyl ether: 4-methylphenol $(0.50 \mathrm{~g}, 4.6 \mathrm{mmol})$ used to yield a dark yellow oil $(0.67 \mathrm{~g}, 98 \%) ; R_{f}=0.4(10 \%$ EtOAc/pet. ether.); ${ }^{1} \mathrm{H}$ NMR $\left(400 \mathrm{MHz}, \mathrm{CDCl}_{3}\right) \delta=7.11-7.05(\mathrm{~m}$, $2 \mathrm{H}, \mathrm{ArH}), 6.86-6.79(m, 2 \mathrm{H}, \mathrm{ArH}), 6.12-6.00\left(m, 1 \mathrm{H}, \mathrm{CH}=\mathrm{CH}_{2}\right)$, 5.44-5.38 $\left(m, 1 \mathrm{H}, \mathrm{CH}=\mathrm{CH}_{\alpha} \mathrm{H}_{\beta}\right), 5.30-5.25\left(m, 1 \mathrm{H}, \mathrm{CH}=\mathrm{CH}_{a} H_{\beta}\right)$, $4.52\left(m, 2 \mathrm{H}, \mathrm{CH}_{2}\right), 2.29\left(\mathrm{~s}, 3 \mathrm{H}, \mathrm{CH}_{3}\right) \mathrm{ppm}$; Data in agreement with literature. ${ }^{23}$

4-(allyloxy)-chlorobenzene: 4-chlorophenol (1.00 g, $7.8 \mathrm{mmol})$ used to yield a yellow oil $(0.67 \mathrm{~g}, 98 \%) ; \mathrm{R}_{\mathrm{f}}=0.4(10 \% \mathrm{EtOAc} /$ pet. ether.); ${ }^{1} \mathrm{H}$ NMR $\left(400 \mathrm{MHz}, \mathrm{CDCl}_{3}\right) \delta=7.23(d, J=9.0 \mathrm{~Hz}, 2 \mathrm{H}$, $\operatorname{Ar} H), 6.84(d, J=9.0 \mathrm{~Hz}, 2 \mathrm{H}, \mathrm{ArH}), 6.09-5.98\left(m, 1 \mathrm{H}, \mathrm{CH}=\mathrm{CH}_{2}\right)$, 5.45-5.37 $\left(m, 1 \mathrm{H}, \mathrm{CH}=\mathrm{CH}_{\alpha} \mathrm{H}_{\beta}\right), 5.33-5.26\left(m, 1 \mathrm{H}, \mathrm{CH}=\mathrm{CH}_{\alpha} H_{\beta}\right)$, 4.54-4.48 ( $\left.m, 2 \mathrm{H}, \mathrm{CH}_{2}\right)$ ppm; Data in agreement with literature. ${ }^{24}$

4-(allyloxy)-bromobenzene: 4-bromophenol (2.00 g, $11.6 \mathrm{mmol})$ used to yield a yellow oil $(2.32 \mathrm{~g}, 94 \%$ yield $) ; R_{f}=0.4(10 \%$ EtOAc/pet. ether.); ${ }^{1} \mathrm{H}$ NMR $\left(400 \mathrm{MHz}, \mathrm{CDCl}_{3}\right) \delta=7.37(d, J=9.0$ $\mathrm{Hz}, 2 \mathrm{H}, \operatorname{Ar} H), 6.80(d, J=9.0 \mathrm{~Hz}, 2 \mathrm{H}, \operatorname{ArH}), 6.03(d d t, J=17.2$, 10.5, $\left.5.3 \mathrm{~Hz}, 1 \mathrm{H}, \mathrm{CH}=\mathrm{CH}_{2}\right), 5.40(d d, J=17.3,1.6 \mathrm{~Hz}, 1 \mathrm{H}$, $\left.\mathrm{CH}=\mathrm{CH}_{\alpha} \mathrm{H}_{\beta}\right), 5.30\left(d d, J=10.5,1.4 \mathrm{~Hz}, 1 \mathrm{H}, \mathrm{CH}=\mathrm{CH}_{\alpha} H_{\beta}\right), 4.53-$ $4.49\left(m, 2 \mathrm{H}, \mathrm{CH}_{2}\right)$ ppm; Data in agreement with literature. ${ }^{25}$

Methyl-4-allyloxybenzoate: methyl-4-hydroxylbenzoate $(5.00 \mathrm{~g}$, $32.9 \mathrm{mmol})$ used to yield a colourless oil $(6.06 \mathrm{~g}, 96 \%$ yield $) ; R_{\mathrm{f}}=$ 0.4 (10\% EtOAc/pet. ether.); ${ }^{1} \mathrm{H}$ NMR $\left(400 \mathrm{MHz}, \mathrm{CDCl}_{3}\right) \delta=8.01-$ $7.95(m, 2 \mathrm{H}, \mathrm{ArH}), 6.95-6.90(m, 2 \mathrm{H}, \mathrm{ArH}), 6.05(d d t, J=17.2$, 10.5, $\left.5.3 \mathrm{~Hz}, 1 \mathrm{H}, \mathrm{CH}=\mathrm{CH}_{2}\right), 5.42(d q, J=17.2,1.6 \mathrm{~Hz}, 1 \mathrm{H}$, $\left.\mathrm{CH}=\mathrm{CH}_{\alpha} \mathrm{H}_{\beta}\right), 5.31\left(d q, J=10.5,1.4 \mathrm{~Hz}, 1 \mathrm{H}, \mathrm{CH}=\mathrm{CH}_{\alpha} H_{\beta}\right), 4.59(d t$, $\left.J=5.3,1.6 \mathrm{~Hz}, 2 \mathrm{H}, \mathrm{CH}_{2}\right) 3.88\left(\mathrm{~s}, 3 \mathrm{H}, \mathrm{CH}_{3}\right) \mathrm{ppm}$; Data in agreement with literature. ${ }^{26}$

O-allyl-guaiacol: 2-methoxy-phenol $(3.60 \mathrm{~mL}, 32.9 \mathrm{mmol})$ used to yield a yellow oil $(4.96 \mathrm{~g}, 92 \%$ yield $) ; R_{f}=0.4(10 \% \mathrm{EtOAc} /$ pet. ether.); ${ }^{1} \mathrm{H}$ NMR $\left(400 \mathrm{MHz}, \mathrm{CDCl}_{3}\right) \delta=6.96-6.85(m, 4 \mathrm{H}, \mathrm{ArH})$, $6.10\left(d d t, \mathrm{~J}=17.2,10.7,5.4 \mathrm{~Hz}, 1 \mathrm{H}, \mathrm{CH}=\mathrm{CH}_{2}\right), 5.41(d q, \mathrm{~J}=17.3$, $\left.1.6 \mathrm{~Hz}, 1 \mathrm{H}, \mathrm{CH}=\mathrm{CH}_{\alpha} \mathrm{H}_{\beta}\right), 5.28(d q, J=10.5,1.4 \mathrm{~Hz}, 1 \mathrm{H}$, $\left.\mathrm{CH}=\mathrm{CH}_{\alpha} H_{\beta}\right), 4.63-4.59\left(m, 2 \mathrm{H}, \mathrm{CH}_{2}\right), 3.87\left(\mathrm{~s}, 3 \mathrm{H}, \mathrm{CH}_{3}\right)$ ppm; Data in agreement with literature. ${ }^{27}$

1-allyloxy-4-methoxybenzene: 2-methoxy-phenol (1.75 g, 14.1 $\mathrm{mmol})$ used to yield a colourless oil $(2.22 \mathrm{~g}, 96 \%$ yield $) ; \mathrm{R}_{\mathrm{f}}=0.4(10 \%$ EtOAc/pet. ether.); ${ }^{1} \mathrm{H}$ NMR $(400 \mathrm{MHz}, \mathrm{CDCl} 3) \delta=6.89-6.81(m, 4 \mathrm{H}$, ArH), 6.05 (ddt, J = 17.3, 10.6, $\left.5.3 \mathrm{~Hz}, 1 \mathrm{H}, \mathrm{CH}=\mathrm{CH}_{2}\right), 5.40(d q, \mathrm{~J}=$
17.3, $\left.1.6 \mathrm{~Hz}, 1 \mathrm{H}, \mathrm{CH}=\mathrm{CH}_{\mathrm{a}} \mathrm{H}_{\beta}\right), 5.27(d q, \mathrm{~J}=10.5,1.4 \mathrm{~Hz}, 1 \mathrm{H}$, $\left.\mathrm{CH}=\mathrm{CH}_{\mathrm{a}} \mathrm{H}_{\beta}\right), 4.51-4.47(m, 2 \mathrm{H}, \mathrm{CH} 2), 3.77\left(s, 3 \mathrm{H}, \mathrm{CH}_{3}\right) \mathrm{ppm}$.

General procedure for the preparation of 2-allylphenols: To a flask containing O-allyl ether (1.0 eq), ethylene glycol (2 mol\%) was added. The reactants were then allowed to heat to $200{ }^{\circ} \mathrm{C}$ under argon and refluxed for $16 \mathrm{~h}$, followed by direct purification by column chromatography to give the 2-allylphenol.

2-allyl-4-methylphenol: 4-methylphenyl allyl ether $(0.60 \mathrm{~g}, 4.1$ $\mathrm{mmol})$ used to yield a yellow oil $(0.48 \mathrm{~g}, 80 \%$ yield $) ; R_{f}=0.3(10 \%$ EtOAc/pet. ether.); ${ }^{1} \mathrm{H}$ NMR $\left(400 \mathrm{MHz}, \mathrm{CDCl}_{3}\right) \delta=6.96-6.90(\mathrm{~m}$, $2 \mathrm{H}, \operatorname{ArH}), 6.75-6.69(m, 1 \mathrm{H}, \operatorname{Ar} H), 6.08-5.96(m, 1 \mathrm{H}, \mathrm{CH}=)$, 5.21$5.12\left(m, 2 \mathrm{H},=\mathrm{CH}_{2}\right), 4.82($ broad $s, 1 \mathrm{H}, \mathrm{OH}), 3.39(d t, J=6.3,1.6$ $\left.\mathrm{Hz}, 2 \mathrm{H}, \mathrm{CH}_{2}\right), 2.27\left(\mathrm{~s}, 3 \mathrm{H}, \mathrm{CH}_{3}\right) \mathrm{ppm}$; Data in agreement with literature. ${ }^{28}$

2-allyl-4-chlorophenol: 4-(allyloxy)-chlorobenzene (1.18 g, 7.0 $\mathrm{mmol})$ used to yield a yellow oil $(0.89 \mathrm{~g}, 76 \%$ yield $) ; R_{f}=0.3(10 \%$ EtOAc/pet. ether.); ${ }^{1} \mathrm{H}$ NMR $\left(400 \mathrm{MHz}, \mathrm{CDCl}_{3}\right) \delta=7.11-7.06(\mathrm{~m}$, $2 \mathrm{H}, \operatorname{ArH}), 6.76-6.72(m, 1 \mathrm{H}, \mathrm{ArH}), 5.98(d d t, J=16.8,10.3,6.4$ $\mathrm{Hz}, 1 \mathrm{H}, \mathrm{CH}=), 5.22-5.13\left(\mathrm{~m}, 2 \mathrm{H},=\mathrm{CH}_{2}\right), 5.00($ broad $s, 1 \mathrm{H}, \mathrm{OH})$, $3.37\left(d t, J=6.3,1.6 \mathrm{~Hz}, 2 \mathrm{H}, \mathrm{CH}_{2}\right) \mathrm{ppm}$; Data in agreement with literature. $^{24}$

2-Allyl-4-bromophenol: 4-(allyloxy) bromobenzene (2.00 g, 9.4 $\mathrm{mmol})$ used to yield a yellow solid $\left(1.44 \mathrm{~g}, 72 \%\right.$ yield); $R_{\mathrm{f}}=0.3$ (10\% EtOAc/pet. ether.); m.p. 54-56 ${ }^{\circ} \mathrm{C}$ (lit. $\left.{ }^{11}: 58-59{ }^{\circ} \mathrm{C}\right) ;{ }^{1} \mathrm{H}$ NMR $\left(400 \mathrm{MHz}, \mathrm{CDCl}_{3}\right) \delta=7.25-7.20(m, 2 \mathrm{H}, \mathrm{Ar} H), 6.71-6.68(m, 1 \mathrm{H}$, $\mathrm{ArH}), 6.03-5.92(\mathrm{~m}, 1 \mathrm{H}, \mathrm{CH}=), 5.22-5.13\left(\mathrm{~m}, 2 \mathrm{H},=\mathrm{CH}_{2}\right), 4.96$ (broad s, $1 \mathrm{H}, \mathrm{OH}$ ), $3.37\left(d t, J=6.4,1.6 \mathrm{~Hz}, 2 \mathrm{H}, \mathrm{CH}_{2}\right.$ ) ppm; Data in agreement with literature. ${ }^{29}$

Methyl-3-allyl-4-hydroxybenzoate: methyl 4-allyloxybenzoate $(6.00 \mathrm{~g}, 31.2 \mathrm{mmol})$ used to yield a white solid $(4.50 \mathrm{~g}, 75 \%$ yield); $\mathrm{R}_{\mathrm{f}}=0.3$ (25\% EtOAc/pet. ether.); m.p. 93-95 ${ }^{\circ} \mathrm{C}$ (lit. $\left.{ }^{10}: 89-90{ }^{\circ} \mathrm{C}\right)$; ${ }^{1} \mathrm{H}$ NMR $\left(400 \mathrm{MHz}, \mathrm{CDCl}_{3}\right) \delta=7.87-7.82(\mathrm{~m}, 2 \mathrm{H}, \mathrm{ArH}), 6.85-6.82$ $(m, 1 \mathrm{H}, \operatorname{ArH}), 6.07-5.95(m, 1 \mathrm{H}, \mathrm{CH}=), 5.49$ (broad $s, 1 \mathrm{H}, \mathrm{OH})$, 5.22-5.14 $\left(m, 2 \mathrm{H},=\mathrm{CH}_{2}\right), 3.88\left(\mathrm{~s}, 3 \mathrm{H}, \mathrm{CH}_{3}\right), 3.44(\mathrm{dt}, \mathrm{J}=6.3,1.7$ $\left.\mathrm{Hz}, 2 \mathrm{H}, \mathrm{CH}_{2}\right) \mathrm{ppm}$; Data in agreement with literature. ${ }^{30}$

2-Allyl-6-methoxyphenol: O-allyl-guaiacol $(4.00 \mathrm{~g}, 24.4 \mathrm{mmol})$ used to yield a yellow oil $(2.28 \mathrm{~g}, 57 \%$ yield $)$. $R_{f}=0.4(10 \%$ EtOAc/pet. ether.); ${ }^{1} \mathrm{H}$ NMR $\left(400 \mathrm{MHz}, \mathrm{CDCl}_{3}\right) \delta=6.83-6.72(\mathrm{~m}$, $3 \mathrm{H}, \mathrm{ArH}$ ), 6.01 (ddt, $\mathrm{J}=16.8,10.0,6.5 \mathrm{~Hz}, 1 \mathrm{H}, \mathrm{CH}=$ ), 5.70 (broad $s, 1 \mathrm{H}, \mathrm{OH}), 5.12-5.02\left(\mathrm{~m}, 2 \mathrm{H},=\mathrm{CH}_{2}\right), 3.88\left(\mathrm{~s}, 3 \mathrm{H}, \mathrm{CH}_{3}\right), 3.42(d t$, $\left.J=6.5,1.5 \mathrm{~Hz}, 2 \mathrm{H}, \mathrm{CH}_{2}\right) \mathrm{ppm}$; Data in agreement with literature. ${ }^{31}$ 2-allyl-4-methoxyphenol: 1-allyloxy-4-methoxybenzene (2.22 g, $13.5 \mathrm{mmol})$ used to yield a yellow oil $(1.20 \mathrm{~g}, 54 \%$ yield $) . R_{f}=0.4$ (10\% EtOAc/pet. ether.); ${ }^{1} \mathrm{H} \mathrm{NMR}\left(600 \mathrm{MHz}, \mathrm{CDCl}_{3}\right) \delta=6.76-6.73$ $(m, 1 \mathrm{H}, \mathrm{ArH}), 6.70-6.66(m, 2 \mathrm{H}, \mathrm{ArH}), 6.00(d d t, J=17.5,9.6,6.4$ $\mathrm{Hz}, 1 \mathrm{H}, \mathrm{CH}=), 5.18-5.13\left(\mathrm{~m}, 2 \mathrm{H},=\mathrm{CH}_{2}\right), 4.70$ (broad $\left.s, 1 \mathrm{H}, \mathrm{OH}\right)$, $3.76\left(s, 3 \mathrm{H}, \mathrm{CH}_{3}\right), 3.38\left(d t, J=6.4,1.6 \mathrm{~Hz}, 2 \mathrm{H}, \mathrm{CH}_{2}\right) \mathrm{ppm}$.

General electrochemical procedure for iodocyclisation of 2allylphenols: A graphite rod working-electrode $\left(4.12 \mathrm{~cm}^{2}\right.$ area) was first coated with a layer $\mathrm{Zn}$ by placing it into an undivided cell containing a $0.1 \mathrm{M} \mathrm{ZnCl}_{2 \text { (aq.) }}$ solution with $\mathrm{K}_{2} \mathrm{CO}_{3}(0.04 \mathrm{~g})$. A silver wire quasi reference-electrode $\left(0.79 \mathrm{~cm}^{2}\right.$ area) and a $\mathrm{Zn}$ plate counter-electrode $\left(2.00 \mathrm{~cm}^{2}\right.$ area) were added and all electrodes were then connected to a potentiostat. The voltage was set to $1.2 \mathrm{~V}$ for $800 \mathrm{~s}$ (34 C passed, $352.99 \mu \mathrm{mol} \mathrm{e}^{-}, 11.54 \mathrm{mg} \mathrm{Zn}$ deposited. According to the amount of 2-allylphenol used, the time could be switched to satisfy $40 \mathrm{~mol} \% \mathrm{Zn}$ ). These electrodes were 
then carefully cleaned with water and acetone and placed into a flame-dried divided ' $\mathrm{H}$ ' cell (Zn-coated graphite and Ag wire in one chamber, $\mathrm{Pt}$ wire in the other chamber). Each side was charged with $10 \mathrm{ml}$ anhydrous $\mathrm{MeCN}$ and $\mathrm{LiClO}_{4}(0.32 \mathrm{~g})$ to make a $0.3 \mathrm{M}$ solution. 2-allylphenol (1.0 eq) and sodium iodide ( $4.0 \mathrm{eq})$ were added to the anode side. The reaction mixture was then allowed to heat and stir vigorously at $60^{\circ} \mathrm{C}$ under argon with a $+1.2 \mathrm{~V}$ constant potential to the anode for $16 \mathrm{~h}$ before being cooled to room temperature. The reaction mixture was then treated with saturated sodium thiosulfate solution and extracted with DCM (3 $\times 20 \mathrm{~mL}$ ). The organic layer was dried over magnesium sulfate and concentrated under vacuum followed then purified by column chromatography to give the final iodo-cyclized product.

2-(iodomethyl)-2,3-dihydro-benzofuran: 2-allylphenol $(0.10 \mathrm{~mL}$, $0.8 \mathrm{mmol})$ and sodium iodide $(0.48 \mathrm{~g}, 3.2 \mathrm{mmol})$ used to yield a yellow oil $(0.19 \mathrm{~g}, 99 \%$ yield $) ; R_{f}=0.5(10 \%$ EtOAc/pet. ether. $) ;{ }^{1} \mathrm{H}$ NMR $\left(600 \mathrm{MHz}, \mathrm{CDCl}_{3}\right) \delta=7.19-7.12(m, 2 \mathrm{H}, \mathrm{Ar} H), 6.89(m, 1 \mathrm{H}$, $\operatorname{ArH}), 6.80(d, J=8.0 \mathrm{~Hz}, 1 \mathrm{H}, \operatorname{ArH}), 4.89(m, 1 \mathrm{H}, \mathrm{OCH}), 3.45(d d$, $\left.J=10.1,4.9 \mathrm{~Hz}, 1 \mathrm{H}, \mathrm{ICH} \mathrm{H}_{\beta}\right), 3.40(d d, J=15.9,9.1 \mathrm{~Hz}, 1 \mathrm{H}$, $\left.\mathrm{CH}_{\alpha} \mathrm{H}_{\beta}\right), 3.35\left(d d, J=10.1,7.6 \mathrm{~Hz}, 1 \mathrm{H}, \mathrm{ICH}_{\alpha} H_{\beta}\right), 3.05(d d, J=15.9$, $\left.6.5 \mathrm{~Hz}, 1 \mathrm{H}, \mathrm{CH}_{\alpha} \mathrm{H}_{\beta}\right) \mathrm{ppm}$; Data in agreement with literature. ${ }^{24}$

2-(iodomethyl)-5-methyl-2,3-dihydro-benzofuran: 2-allyl-4methylphenol $(0.15 \mathrm{~g}, 1.0 \mathrm{mmol})$ and sodium iodide $(0.61 \mathrm{~g}, 4.0$ $\mathrm{mmol})$ used to yield a yellow oil $(0.26 \mathrm{~g}, 93 \%$ yield $) . R_{\mathrm{f}}=0.5(10 \%$ EtOAc/pet. ether.); ${ }^{1} \mathrm{H}$ NMR $\left(400 \mathrm{MHz}, \mathrm{CDCl}_{3}\right) \delta=7.00-6.90(\mathrm{~m}$, $2 \mathrm{H}, \operatorname{ArH}), 6.67(d, J=8.1 \mathrm{~Hz}, 1 \mathrm{H}, \operatorname{ArH}), 4.86(m, 1 \mathrm{H}, \mathrm{OCH}), 3.46-$ $3.30\left(m, 3 \mathrm{H}, \mathrm{CH}_{a} \mathrm{H}_{\beta}, \mathrm{ICH} \mathrm{CH}_{2}\right), 3.01\left(d d, J=15.9,6.5 \mathrm{~Hz}, 1 \mathrm{H}, \mathrm{CH}_{\alpha} H_{\beta}\right)$, $2.28\left(\mathrm{~s}, 3 \mathrm{H}, \mathrm{CH}_{3}\right) \mathrm{ppm}$. Data in agreement with literature. ${ }^{32}$

2-(iodomethyl)-5-chloro-2,3-dihydro-benzofuran: 2-allyl-4chlorophenol $(0.20 \mathrm{~g}, 1.2 \mathrm{mmol})$ and sodium iodide $(0.71 \mathrm{~g}, 4.8$ $\mathrm{mmol})$ used to yield a yellow oil $(0.28 \mathrm{~g}, 81 \%$ yield $) . R_{\mathrm{f}}=0.5(10 \%$ EtOAc/pet. ether.); ${ }^{1} \mathrm{H}$ NMR $\left(400 \mathrm{MHz}, \mathrm{CDCl}_{3}\right) \delta=7.14-7.05(\mathrm{~m}$, $2 \mathrm{H}, \operatorname{Ar} H), 6.69(d, J=8.4 \mathrm{~Hz}, 1 \mathrm{H}, \operatorname{Ar} H), 4.93-4.85(m, 1 \mathrm{H}, \mathrm{OCH})$, 3.46-3.30 $\left(m, 3 \mathrm{H}, \mathrm{ICH}_{2}, \mathrm{CH}_{a} \mathrm{H}_{\beta}\right), 3.03(d d, J=16.2,6.7 \mathrm{~Hz}, 1 \mathrm{H}$, $\left.\mathrm{CH}_{\alpha} H_{\beta}\right)$ ppm. Data in agreement with literature. ${ }^{24}$

2-(iodomethyl)-5-bromo-2,3-dihydro-benzofuran: 2-allyl-4bromophenol $(0.20 \mathrm{~g}, 0.9 \mathrm{mmol})$ and sodium iodide $(0.54 \mathrm{~g}, 3.6$ $\mathrm{mmol})$ used to yield a colourless oil $(0.26 \mathrm{~g}, 83 \%$ yield $) . \mathrm{R}_{\mathrm{f}}=0.5$ (10\% EtOAc/pet. ether.); ${ }^{1} \mathrm{H}$ NMR $\left(400 \mathrm{MHz}, \mathrm{CDCl}_{3}\right) \delta=7.28-7.26$ $(m, 1 \mathrm{H}, \operatorname{Ar} H), 7.24-7.20(m, 1 \mathrm{H}, \operatorname{ArH}), 6.66(d, J=8.5 \mathrm{~Hz}, 1 \mathrm{H}$, $\mathrm{ArH})$, 4.93-4.84 (m, 1H, OCH), 3.45-3.30 (m, 3H, ICH, $\left.\mathrm{CH}_{\alpha} \mathrm{H}_{\beta}\right)$, $3.04\left(d d, J=16.2,6.7 \mathrm{~Hz}, 1 \mathrm{H}, \mathrm{CH}_{\alpha} H_{\beta}\right) \mathrm{ppm} ;{ }^{13} \mathrm{C} \mathrm{NMR}(100 \mathrm{MHz}$, $\left.\mathrm{CDCl}_{3}\right) \delta=158.4,131.1,128.3,128.0,112.7,111.2,82.2,36.0$, 8.6 ppm; HRMS (ESI) calc'd for $\left[\mathrm{C}_{9} \mathrm{H}_{8} \mathrm{IOBr}+\mathrm{H}\right]^{+} 338.8876$, found 338.8876; IR $V_{\max }$ (film) 2952, 1467, 1322, 1229, 1160, 960, 807, $621,540 \mathrm{~cm}^{-1}$.

Methyl-2-(iodomethyl)-2,3-dihydro-1-benzofuran-5-

carboxylate: 3 -allyl-4-hydroxybenzoate $(0.20 \mathrm{~g}, 1.0 \mathrm{mmol})$ and sodium iodide $(0.60 \mathrm{~g}, 4.0 \mathrm{mmol})$ used to yield a white solid $(0.22$ g, $67 \%$ yield). $\mathrm{R}_{\mathrm{f}}=0.3$ (10\% EtOAc/pet. ether.); m.p. $75-77{ }^{\circ} \mathrm{C} ;{ }^{1} \mathrm{H}$ NMR (400 MHz, $\left.\mathrm{CDCl}_{3}\right) \delta=7.90-7.85(m, 2 \mathrm{H}, \mathrm{ArH}), 6.79(d, J=$ $8.3 \mathrm{~Hz}, 1 \mathrm{H}, \mathrm{ArH}), 4.96(\mathrm{~m}, 1 \mathrm{H}, \mathrm{OCH}), 3.87\left(\mathrm{~s}, 3 \mathrm{H}, \mathrm{COOCH}_{3}\right), 3.48-$ $3.34\left(m, 3 \mathrm{H}, \mathrm{CH}_{a} \mathrm{H}_{\beta}, \mathrm{ICH}_{2}\right), 3.06\left(d d, \mathrm{~J}=16.1,6.6 \mathrm{~Hz}, 1 \mathrm{H}, \mathrm{CH}_{a} H_{\beta}\right)$ ppm; ${ }^{13} \mathrm{C}$ NMR $\left(100 \mathrm{MHz}, \mathrm{CDCl}_{3}\right) \delta=166.9,163.2,131.4,126.9$, 126.3, 123.3, 109.3, 82.7, 52.0, 36.0, 8.4 ppm; HRMS (ESI) calc'd for $\left[\mathrm{C}_{11} \mathrm{H}_{11} \mathrm{IO}_{3}+\mathrm{H}\right]^{+} 318.9826$, found 318.9827. IR $V_{\max }$ (film) 2952, $2843,1715,1486,1286,1110,941,846,764,569 \mathrm{~cm}^{-1}$ 2-(iodomethyl)-7-methoxyl-2,3-dihydro-benzofuran: 2-allyl-6methoxyphenol $(0.20 \mathrm{~g}, 1.2 \mathrm{mmol})$ and sodium iodide $(0.72 \mathrm{~g}, 4.8$ $\mathrm{mmol})$ used to yield a brown solid $(0.23 \mathrm{~g}, 64 \%$ yield $) . R_{\mathrm{f}}=0.3$ (10\% EtOAc/pet. ether.); m.p. $61-63{ }^{\circ} \mathrm{C} ;{ }^{1} \mathrm{H}$ NMR (400 MHz, $\left.\mathrm{CDCl}_{3}\right) \delta=6.89-6.72(m, 3 \mathrm{H}, \mathrm{ArH}), 4.99-4.88(m, 1 \mathrm{H}, \mathrm{OCH}), 3.87$ $\left(s, 3 \mathrm{H}, \mathrm{OCH}_{3}\right), 3.55-3.31\left(m, 3 \mathrm{H}, \mathrm{CH}_{\alpha} \mathrm{H}_{\beta}, \mathrm{ICH}_{2}\right), 3.10(d d, J=15.8$, $\left.6.9 \mathrm{~Hz}, 1 \mathrm{H}, \mathrm{CH}_{\alpha} \mathrm{H}_{\beta}\right) \mathrm{ppm} ;{ }^{13} \mathrm{C} \mathrm{NMR}\left(150 \mathrm{MHz}, \mathrm{CDCl}_{3}\right) \delta=147.7$, $144.6,127.0,121.6,117.3,111.4,82.3,56.1,36.7,9.0$ ppm; HRMS (ESI) calc'd for $\left[\mathrm{C}_{10} \mathrm{H}_{11} \mathrm{IO}_{2}+\mathrm{H}\right]^{+} 290.9876$, found 290.9874 . IR Vmax (film) 2935, 1490, 1436, 1197, 1078, 926, 763, 611 $\mathrm{cm}^{-1}$.

2-(iodomethyl)-5-methoxyl-2,3-dihydro-benzofuran: 2-allyl-4methoxyphenol $(0.20 \mathrm{~g}, 1.2 \mathrm{mmol})$ and sodium iodide $(0.72 \mathrm{~g}, 4.8$ mmol) used to yield a yellow solid $(0.28 \mathrm{~g}, 79 \%$ yield $) . R_{f}=0.3$ (10\% EtOAc/pet. ether.); m.p. $61-63^{\circ} \mathrm{C}$ (lit. $\left.{ }^{15}: 62-63.3^{\circ} \mathrm{C}\right) ;{ }^{1} \mathrm{H}$ NMR $\left(400 \mathrm{MHz}, \mathrm{CDCl}_{3}\right) \delta=6.76-6.73(\mathrm{~m}, 1 \mathrm{H}, \mathrm{ArH}), 6.71-6.64(\mathrm{~m}, 2 \mathrm{H}$, $\mathrm{ArH}), 4.84$ (dddd, $\mathrm{J}=9.0,7.5,6.6,4.9 \mathrm{~Hz}, 1 \mathrm{H}, \mathrm{OCH}), 3.75(\mathrm{~s}, 3 \mathrm{H}$, $\left.\mathrm{OCH}_{3}\right), 3.45-3.29\left(\mathrm{~m}, 3 \mathrm{H}, \mathrm{CH}_{\alpha} \mathrm{H}_{\beta}, \mathrm{ICH}_{2}\right), 3.01(d d, J=16.1,6.6$ $\left.\mathrm{Hz}, 1 \mathrm{H}, \mathrm{CH}_{\alpha} H_{\beta}\right)$ ppm. Data in agreement with literature. ${ }^{24}$

\section{Acknowledgements}

The authors thank UCL for financial support via a studentship awarded to PWS. The authors also gratefully acknowledge Dr. A. Aliev and Dr. K. Karu for NMR and MS support respectively.

Keywords: Electrochemistry • Synthesis • Mechanisms •

Processes $\cdot$ lodocyclisation

[1] F. Yang, T. Jin, M. Bao, Y. Yamamoto, Chem. Commun. 2011, 47, 45414543.

[2] F. Yang, T. Jin, M. Bao, Y. Yamamoto, Tetrahedron 2011, 67, 1014710155.

[3] T. Okitsu, K. Nakata, K. Nishigaki, N. Michioka, M. Karatani, A. Wada, J. Org. Chem. 2014, 79, 5914-5920.

T. Okitsu, R. T. Nakazawa, A. Wada, Org. Lett. 2008, 10, 4967-4970.

[5] Y-L. Li, J. Li, S-N, Yu, J-B Wang, Y-M. Yu, J. Deng, Tetrahedron 2015 , 71, 8271-8277.

[6] D. Goyal, A. Kaur, B. Goyal, ChemMedChem. 2018, 13, 1275-1299.

[7] X-L. Xu, Y-R, Yang, X-F. Mo, J-L. Wei, X-J. Zhang, Q-D. You, Eur. J. Med. Chem. 2017, 137, 45-62.

[8] R. J. Nevagi, S. N. Dighe, S. N. Dighe, Eur. J. Med. Chem. 2015, 97, 561-581.

[9] H. Khanam, Shamsuzzaman, Eur. J. Med. Chem. 2015, 97, 483-504.

[10] X-Y. Ye, C. L. Morales, Y. Wang, K. A. Rossi, S. E. Malmstrom, M. Abousleiman, L. Sereda, A. Apedo, J. A. Robl, K. J. Miller, J. Krupinski, D. A. Wacker, Bioorg. Med. Chem. Lett. 2014, 24, 2539-2545.

[11] M. L. N. Rao, V. N. Murty, S. Nand, Org. Biomol. Chem. 2017, 15, 94159423.

[12] J-t. Liu, C. J. Simmons, H. Xie, F. Yang, X-I. Zhao, Y. Tang, W. Tang, Adv. Synth. Catal. 2017, 359, 693-697.

[13] S. O. Simonetti, E. L. Larghi, A. B. J. Bracca, T. S. Kaufman, Nat. Prod. Rep. 2013, 30, 941-969.

[14] K. Orito, T. Hatakeyama, M. Takeo, H. Suginome, M. Tokuda, Synthesis 1997, 23-25.

[15] V. A. Mahajan, P. D. Shinde, A. S. Gajare, M. Karthikeyan, R. D. Wakharkar, Green Chem. 2002, 4, 325-327.

[16] P. W. Seavill, K. B. Holt, J. D. Wilden, Green Chem. 2018, 20, 5474-5478.

[17] A. I. Popov, D. H. Geske, J. Am. Chem. Soc. 1958, 80, 5346-5349.

[18] T. Iwaasita, M. C. Giordano, Electrochim. Acta. 1969, 14, 1045-1059. 
[19] R. L. Geerts, J. C. Huffman, K. G. Caulton, Inorg. Chem. 1986, 25, $1803-$ 1805.

[20] T. Kometani, D. S. Watt, T. Ji, Tetrahedron Lett. 1985, 26, 2043-2046.

[21] T. Kometani, D. S. Watt, T. Ji, T. Fitz, J. Org. Chem. 1985, 50, 53845387.

[22] C. Hansch, A. Leo, R. W. Taft, Chem. Rev. 1991, 165-195.

[23] A. Saha, J. Leazer, R. S. Varma, Green Chem., 2012, 14, 67-71.

[24] W. Chen, X-D. Yang, J-L. Yang, X-Q. Wang, G-L. Zhang, H-B. Zhang, Org. Biomol. Chem., 2011, 9, 4250-4255.

[25] C. Chardin, J. Rouden, S. Livi, J. Baudoux, Green Chem., 2017, 19, 5054-5059.

[26] M. Chouhan, K. Kumar, R. Sharma, V. Grover, V. P. Nair, Tetrahedron Lett., 2013, 54, 4540-4543.
[27] A. Llevot, B. Monney, S. Behrens, M. A. R. Meier, Chem. Commun., 2017, 53, 5175-5178.

[28] M. Rehan, R. Nallagonda, B. G. Das, T. Meena, P. Ghorai, J. Org. Chem., 2017, 82, 3411-3424.

[29] R. Bujok, M. Bieniek, A. Michrowska, A. Sarosiek, H. Stępowska, D. Arlt, K. Grela, K. J. Org. Chem., 2004, 69, 6894-6896.

[30] J. A. Burlison, L. Neckers, A. B. Smith, A. Maxwell, B. S. J. Blagg, J. Am. Chem. Soc., 2006, 128, 15529-15536.

[31] M. Yoshida, M. Higuchi, K. Shishido, Org. Lett., 2009, 11, 4752-4755.

[32] M. Fousteris, C. Chevrin, J. Le Bras, J. Muzart, Green Chem., 2006, 8, 522-523. 
WILEY-VCH

\section{Entry for the Table of Contents}

\section{FULL PAPER}

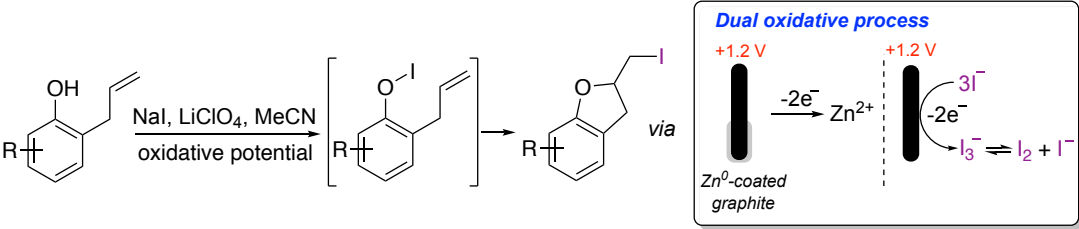

Iodocyclisation of 2-allylphenols can be achieved by 'on-demand' generation of $\mathrm{I}_{2}$ in an electrochemical cell. Associated mechanistic investigations have demonstrated the likely involvement of an iodosylaryl species as the active oxidant.
Author(s), Corresponding Author(s)*

Page No. - Page No.

Title 